Mitteilungen der Österreichischen Geographischen Gesellschaft,

157. Jg. (Jahresband), Wien 2015, S. 229-252

\title{
Typology of Tourist Resorts in Croatia: The Case of South Dalmatia
}

\author{
Ivan Šulc and Vuk Tvrtko OPAČIĆ, both Zagreb*
}

with 9 figures and 2 tables in the text

\section{CONTENTS}

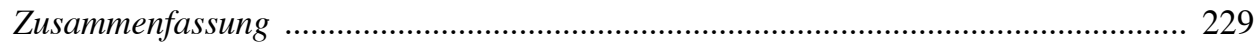

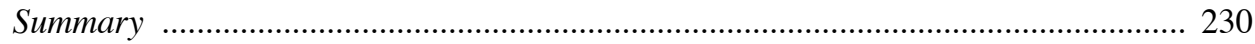

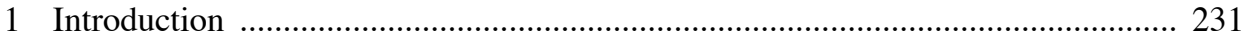

2 Research goals and research area ...................................................................... 234

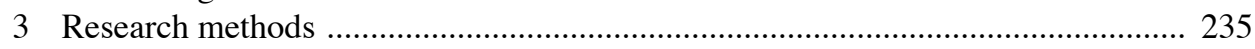

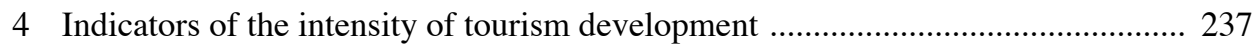

5 Typology of tourist resorts in South Dalmatia ....................................................... 246

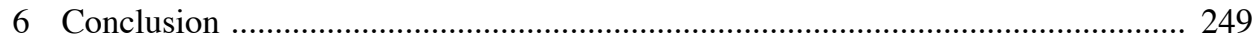

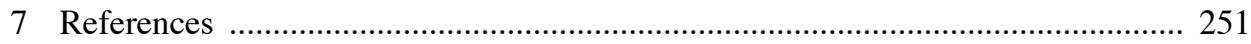

\section{Zusammenfassung}

Typologie von Tourismusorten in Kroatien: das Beispiel Süddalmatiens

Das Hauptziel der Untersuchung ist das Anwenden einer auf dem Niveau der Tourismusentwicklung beruhenden Typologie von Tourismusorten auf Süddalmatien, den südlichsten Abschnitt der kroatischen Küste.

Die Untersuchung nützt die methodischen Instrumente der geographischen Analyse und Synthese - sie analysiert statistische Daten, führt eine GIS-Analyse durch und visualisiert Geoinformationen durch thematische Karten. Die Typologie stïtzt sich auf die folgenden Indikatoren nach Siedlungen: (1) Zahl der Gästebetten, (2) Zahl der Touristen, (3) Zahl der Übernachtungen, (4) Koeffizient touristischer Funktionalität (Gästebetten pro 100 Einwohner), (5) Gästebettendichte (Gästebetten pro $\mathrm{km}^{2}$ ), (6) Touristendichte (Touristen pro $\mathrm{km}^{2}$ ), (7) Klassifizierung der Tourismusorte nach einer kroatischen Regelung, welche sie nach quantitativen und qualitativen Kriterien in vier Klassen einteilt,

\footnotetext{
* Ivan Šulc, M.S. (Master of Geography), assistant - junior researcher and PhD student, Vuk Tvrtko OpAČIĆ, $\mathrm{PhD}$, Associate Professor, both University of Zagreb, Faculty of Science, Department of Geography, Marulićev trg 19/II, HR-10000 Zagreb, Croatia; email: isulc@geog.pmf.hr, vtopacic@geog.pmf.hr
} 
um die Höhe der Kurtaxe zu bestimmen und die Notwendigkeit eines Tourismusbüros zu ermitteln. Um zur endgültigen Typologie zu gelangen, wurden je Indikator und Ort Punkte vergeben, deren Summe den Typ ergibt.

Die Typologie bestätigt die ungleiche räumliche Verteilung der Tourismusentwicklung in Süddalmatien mit ihrem Fokus auf der Stadtregion von Dubrovnik. Eine stärkere Tourismusentwicklung gibt es fast ausschließlich an der Küste, während sie im Landesinneren nur sporadisch und geringer ist. Allerdings sind auch dort einige Siedlungen (besonders kleine) sehr vom Tourismus abhängig und deshalb starkem physischen und sozialen Druck durch den Tourismus ausgesetzt.

Die Typologie weist auch auf Tourismusorte ersten und zweiten Ranges in Süddalmatien hin, die touristische Zentren und Träger der Tourismusentwicklung sind. Sie zeigt aber auch, dass es viele kleine Siedlungen mit einem einfachen touristischen Angebot gibt, die mehr oder weniger am Tourismus orientiert sind. Deshalb kann die Typologie als erster Schritt einer touristischen Regionalisierung Süddalmatiens verstanden werden, die funktional komplette touristische Raumeinheiten definiert, welche über ein qualitativ hochwertiges Angebot verfügen und in der Lage sind, Tourismusentwicklung und Auswirkungen des Tourismus erfolgreich zu steuern, was bis jetzt nur in einigen führenden Tourismusorten der Fall ist.

Schlagwörter: Typologie, Tourismusorte, Süddalmatien, Kroatien

\section{Summary}

The main goal of the research is to apply the typology of tourist resorts based on the level of tourism development to the example of South Dalmatia, the southernmost littoral part of Croatia.

The research is based on the methodological instruments of geographical analysis and synthesis and includes analysis of statistical data, GIS analysis and visualisation of spatial data in GIS using thematic maps. The typology was formed using the following indicators on the level of settlements: (1) number of tourist beds, (2) number of tourist arrivals, (3) number of overnight stays, (4) co-efficient of tourism functionality (number of tourist arrivals per 100 inhabitants), (5) density of tourist beds (number of tourist beds per square kilometre), (6) density of tourist arrivals (number of tourist arrivals per square kilometre), (7) tourist class assigned to the tourist resort according to a Croatian regulation that categorises basic tourist resorts into four classes using quantitative and qualitative criteria to determine the level of the sojourn tax and the possibility of founding a tourist board.To achieve the final typology, every indicator was scored for every tourist resort.

The typology confirms the uneven spatial distribution of tourism development in South Dalmatia with its focus on the Dubrovnik urban region. The higher level of tourism development is concentrated almost exclusively on the coastal resorts, while the interior is characterised by sporadic and low tourism development. However, even in areas with a lower level of tourism development, some settlements - small ones particularly - are highly dependent on tourism and, therefore, characterised by high pressure of tourism on the physical and social environment. 
The typology resulted in determining a certain number of first- and second-level tourist resorts, tourist centres that are carriers of tourism development in South Dalmatia, and a large number of small settlements with a simpler tourism supply, although more or less oriented to tourism. Therefore, the typology can be treated as a first step towards a functional tourism regionalisation of South Dalmatia forming functionally complete tourism units that have a quality tourism supply and that are capable of successful management of tourism development and tourism impacts, which is now partly present only in leading tourist destinations.

Keywords: typology, tourist resorts, South Dalmatia, Croatia

\section{Introduction}

In the period of socio-economic transition from the planned Socialist economy to the Capitalist market economy and the recent economic crisis, which seems to have affected Croatia more seriously than the other members of the European Union (EU), tourism is regarded as the most prosperous and successful economic activity. However, it is marked by many issues that prevent proper tourism valorisation of the Croatian territory, fulfilling desirable economic objectives (creating new work places and developing other economic activities) and achieving a more balanced regional development. Tourism in Croatia faces major unevenness in spatial distribution (resulting in the saturation of the narrow coastal zone by over-construction, overuse of space, traffic congestions etc.), high seasonality and dependency upon coastal tourism. Another issue is inadequate territorial organisation of tourist boards, the main entities aimed at promoting the tourism supply on the level of tourist destinations and at gathering relevant participants in tourism, attempting to set the hierarchy of tourist destinations. Therefore, an appropriate geographical regionalisation of Croatia in relation to tourism based on the level of tourism development in tourist destinations still does not exist. But that would be an essential factor in achieving a more balanced tourism development.

Creating a typology of spatial units is one of frequently applied methods in geography and related sciences. Its primary function is to define, simplify and arrange data in order to make it comparable (LUKIĆ 2012). LUKIĆ (2012, p. 51) stresses that "typology as a research method should take into account four basic rules: consistency, completeness, thoroughness and sufficient discriminatory sharpness". PATTON (2002, p. 457) observed that typologies are "classification systems made up of categories that divide some aspect of the world into parts along a continuum" (cited in Prideaux, 2009, p. 28). Although the typology of spatial units is often applied as a method in geography, it should be emphasised that typologies are rarely based only on quantitative indicators due to the frequent lack of reliable statistical data. One of the main disadvantages of this method is static observation of the space (LuKić 2012). Prideaux (2009, p. 28) identifies two basic approaches in typologies of tourist destinations - (a) those based on the observed morphological characteristics of tourist resorts, and (b) those that investigate the factors that influence the individual's decision to travel. 
The disaggregated approach to the typology of tourist resorts is used to classify tourist resorts into groups according to defined distinction criteria and indicators. The expected result of a typology of tourist resorts conducted in that way is classification of tourist resorts according to the level of tourism development, based on objective quantitative indicators derived from tourism statistics.

Typologies of tourist resorts vary between authors and countries. It is important to emphasise that there are no universal criteria for determining the typology of tourist resorts according to the level of tourism development as an objective basis for geographic regionalisation in relation to tourism.

Thus, Pollice (2002) proposes classification of tourism regions according to five criteria: (1) spatial configuration of the tourism region; (2) orientation in the receptive tourism supply; (3) level of co-operation within the system of tourism supply; (4) the relation between tourism and the territory; and (5) the evolutionary stage of the local tourism system. The proposed criteria emphasise the close and inseparable relation of tourism and territory, being aware of the fact that tourism is based on geographical space and that tourism changes it.

LozATo-Giotart $(1987 ; 1993,2008)$ developed an extensive and detailed typology of tourist areas. All tourist areas are divided into two basic groups: (1) polyvalent tourist areas (having other functions beside tourism); and, (2) specialised tourist areas. Polyvalent tourist areas consist of: (1a) seaside and lacustrial areas (traditional seaside type, lacustrial type, partially seaside type); (1b) urban areas (large multipolar and polynuclear cities, small and medium unipolar and mononucleus cities, intermediary cities more or less bipolar and polynuclear); (1c) green and 'rurban' areas (agrotourist polyvalent type, 'rurban' type). Specialised tourist areas are divided into two groups: (1) open areas (seaside type, specialised thermal type, specialised culture sites, winter sports areas); (2) tourist enclaves (enclave type more or less open, enclave type more or less closed) (LoZATO-GIOTART 2008).

Over the last three decades, there have been several proposals for determining the geographic regions of Croatia related to tourism. KLARIć (1990) proposed a three-level regionalisation that comprised the entire national territory and followed the contours of the former large municipalities (administrative organisation during the period of ex-Yugoslavia). The author defined tourism regions as spatial units characterised by similarity in tourism structure reflected in the geographically relevant forms of tourism as a primary element of cohesion within a region, and functional, organisation and marketing relations as a secondary element of cohesion.

The first (highest) level of regionalisation was determined using the most common geographically relevant forms of tourism in Croatia: (1) littoral or seaside tourism; (2) mountain tourism and (3) thermal tourism. Tourist resorts were categorised as seaside, mountain, thermal or 'other' according to the criteria defined by the Federal Bureau of Statistics. KLARIĆ (1990) categorised the municipalities according to the domination of tourism turnover realised by dominant types of tourist resorts (e.g., a municipality, in 
which the largest share of overnight stays was recorded in seaside tourist resorts, was categorised as 'seaside'). They were eventually assigned to one of three tourism regions based on the dominant types of tourism: (1) Adriatic (littoral) region (with seaside tourism and seaside tourist resorts/municipalities); (2) Dinaric (mountain) region (with mountain tourism and tourist resorts/municipalities); and (3) Pannonian-Peri-Pannonian (lowland-hilly) region (with thermal tourism and geographically irrelevant forms of tourism and matching tourist resorts/municipalities). Municipalities that were not assigned to any region were placed in the same region as the central settlement to which they gravitated (e.g., regional centre).

Second-level tourism regions included the classification of municipalities with higher tourism turnover. The classification was conducted according to the level of tourism development and included six basic indicators: (1) the index of tourism functionality (number of tourist beds per 100 inhabitants); (2) number of seats in catering facilities (outside accommodation facilities) per 100 inhabitants; (3) number of tourist arrivals per capita; (4) number of overnight stays per capita; (5) the share of active population employed in the sector of catering and tourism in the total number of active working population; and (6) the share of the Gross Domestic Product recorded in the sector of catering and tourism in the total Gross Domestic Product. Each indicator for each municipality was scored from 1 to 4 . The average scores were arranged by the value, and municipalities were categorised in four classes - one referred to the highest level of tourism development, four referred to the lowest level. The aim was to express the areas of the highest concentration of tourism (municipalities that belonged to Class 1) as the cores of second-level tourism regions.

Accordingly, within the Adriatic (littoral) region five regions were formed: (1) Istria [Istra], (2) Kvarner, (3) North Dalmatia [Sjeverna Dalmacija], (4) Central Dalmatia [Srednja Dalmacija] and (5) South Dalmatia [Južna Dalmacija]. The Dinaric (mountain) region had only one first-class municipality and was not divided into second-level regions. The Pannonian-Peri-Pannonian (lowland-hilly) region did not record any significant concentration of tourism and it was divided into two regions (Central Croatia [Središnja Hrvatska] and East Croatia [Istočna Hrvatska]) according to the physiognomic reflections of tourism. Third-level regions represented municipalities in the period of Socialist Yugoslavia. It is important to emphasise that KLARIĆ's (1990) second-level regions do not match current tourism regions set by the Croatian Tourist Board.

Curić, Glamuzina \& Opačić (2012) investigated the level of achieved tourism development in Croatia on the level of (new) administrative towns and municipalities. They made a typology that included seven relevant indicators of tourism development: (1) number of tourist beds; (2) number of tourist arrivals; (3) number of international tourist arrivals; (4) number of overnight stays; (5) number of international overnight stays; (6) number of tourist arrivals per square kilometre; and (7) number of tourist arrivals per capita. Due to large regional differences in tourism development, the indicators were analysed separately for each large geographical region (Northern Littoral, Southern Littoral, Mountainous Region, Peri-Pannonia and Pannonia) in order to get a better image of the level of tourism development. 
Nevertheless, a contemporary comprehensive typology of tourist resorts in Croatia based on the level of tourism development still does not exist, and it would be essential in achieving more balanced tourism development on a national, regional and local level.

\section{Research goals and research area}

The purpose of this research is to propose and apply to a representative case study a more comprehensive set of criteria and indicators for the typology of tourist resorts, based on tourism development in Croatia. A typology structured in this way should provide a background in creating an organisational and legislative framework for the better cohesion of homogenous spatial units in Croatia.

Therefore, the main goal of the research is to apply the typology of tourist resorts based on the level of tourism development to the example of one particular tourism region in Croatia. The research area comprises the Dubrovnik-Neretva County [Dubrovačko-neretvanska županija] (regional administrative unit - NUTS-3) or the geographical region of South Dalmatia, the southernmost littoral part of Croatia.

This paper is based on tourist resorts defined as resorts that are visited by a larger number of tourists, whether they are permanent human settlements or not, but are equipped to receive tourists and provide for their stay. Therefore, the two main conditions a settlement has to meet to be considered as a tourist resort, are attractiveness (natural amenities, monuments, events etc.) and receptiveness (accommodation units, catering and other services, parks, baths, walking trails, sports courts, playgrounds etc.). Tourist resorts are, however, usually identified with permanent human settlements and in the functional sense they are complex spatial units that have to meet all the everyday needs of tourists and, therefore, have to provide a complete tourism supply (VUKONIĆ \& ČAVLEK 2001).

Significance and definition of a tourist resort differ among different countries. Terminology related to spatial units in tourism is not precisely defined in Anglo-American literature; hence the terms resort and tourist place are used often simultaneously and with the same meaning. MedLiK (2003) defines a tourist resort in the same way as previously defined. PridEAUX (2009) defines tourist resort as a spatial unit, in which tourism is the main activity, giving the example of early seaside resorts and ski towns. WiLLIAMS (2009) makes a distinction between the term resort, which comprehends traditional areas of tourism development (e.g., spas and coastal bathing areas) and the term tourist place, which is related to new tourist destinations (e.g., cities), but he does not give a precise definition of either of them. Nonetheless, this paper uses the term tourist resorts for all settlements, in which tourist beds and/or tourist arrivals were recorded in at least one year in the 2010-2012 period. Out of 227 settlements in South Dalmatia, 107 had registered tourism turnover and were analysed as tourist resorts, while 120 settlements did not have registered tourist turnover and were not included in the analysis (Fig. 1).

South Dalmatian destinations are in different stages of the tourism area life cycle according to ButLER's (1980) model (ŠULC 2014). The main difference exists between 
Dubrovnik (the most famous Croatian tourist destination) and other seaside destinations and other areas with a lower level of tourism development. Besides Dubrovnik, which has developed a comprehensive tourism supply, other seaside tourist resorts are still focused on Sun-\&-Sea tourism supply. Several tourist destinations have been developing other forms of tourism recently, e.g., rural tourism in the Konavle (a landscape southeast of Dubrovnik), wine tourism on the peninsula of Pelješac and ecotourism in the Lower Neretva Region, as well as on the islands of Mljet and Lastovo.

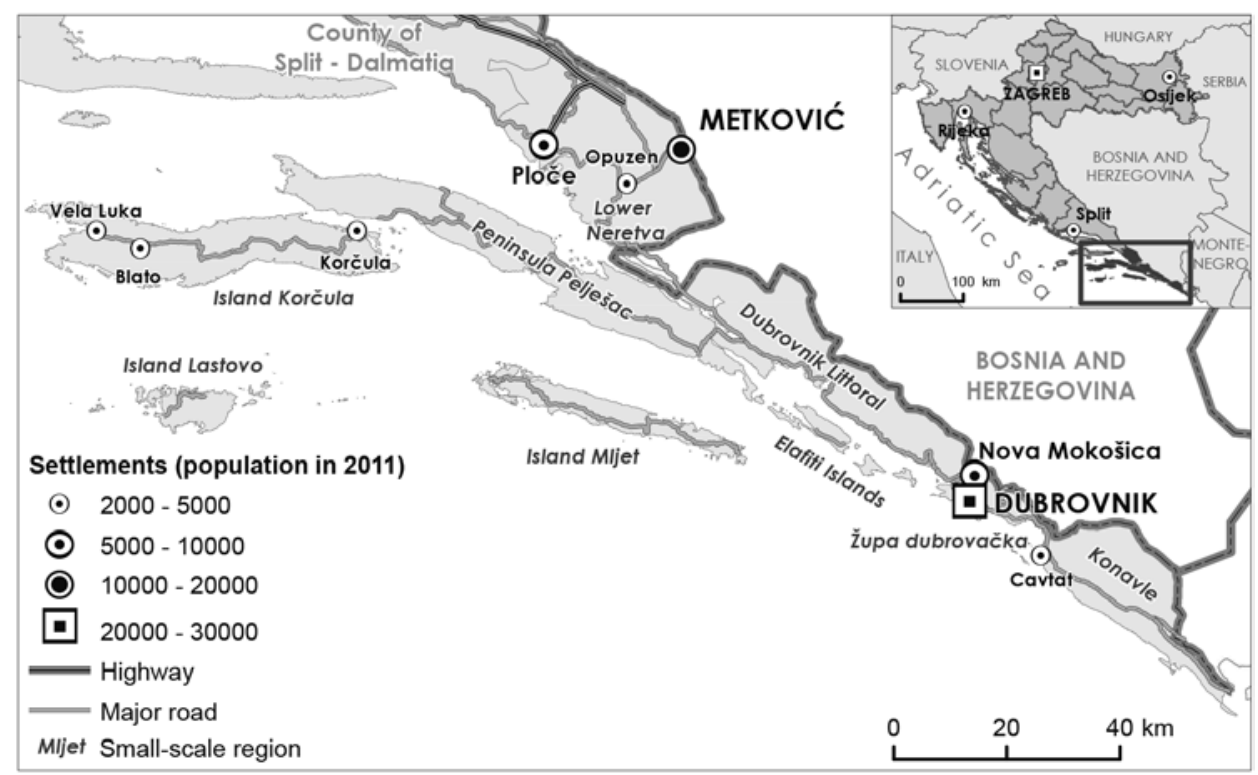

Sources: GIS DATA (2005); ESRI (2014)

Fig. 1: Settlement network in South Dalmatia

\section{Research methods}

The research has been based on the methodological instruments of geographical analysis and synthesis and includes analysis of statistical data (descriptive statistics), Geographical Information System (GIS) analysis and visualisation of spatial data in GIS using thematic maps.

In order to achieve the defined goal, seven selected indicators of tourism demand and supply as well as pressure of tourism on the physical and social environment were scored in order to classify tourist resorts according to the level of tourism development. A typology was formed using the following indicators on the level of settlements: (1) number of tourist beds; (2) number of tourist arrivals; (3) number of overnight stays; (4) co-efficient 
of tourism functionality (number of tourist arrivals per 100 inhabitants) ${ }^{1)}$; (5) density of tourist beds (number of tourist beds per square kilometre) ${ }^{2)}$; (6) density of tourist arrivals (number of tourist arrivals per square kilometre); and (7) tourist class assigned to the particular destination according to the Regulation on Criteria FOR CATEgORISATION OF Tourist Settlements into Tourist Classes (NN 152/08). The Regulation categorises basic tourist resorts into four classes (A, B, C or D) using quantitative and qualitative criteria, aimed at determining the level of the sojourn tax and the feasibility of founding a tourist board.

Indicators for all settlements had been inserted into a GIS database on the basis of which the typology was formed. The numbers of tourist beds, arrivals and overnight stays were calculated as annual averages in the 2010-2012 period, in order to eliminate insignificant oscillations between the years in some settlements. The analysis included 107 settlements that recorded tourist beds, arrivals or overnight stays at least in one year (2010, 2011 or 2012). The settlements that did not register tourist beds, arrivals or overnight stays in any of these years were not included in the analysis.

Settlements were grouped into one out of six classes ${ }^{3)}$ for each indicator (except tourist class). Tested mathematic methods of classification in GIS (quantile, Jenks, geometrical interval, standard deviation) did not prove to be useful for this purpose; hence class boundaries were determined intentionally, in order to reflect differences in the intensity of tourist turnover and impact of tourism on the tourist area. Each indicator in each settlement was assigned from 1 to 6 points according to the criteria in Table 1. The higher points were scored to classes with higher value and lower points to classes with lower value.

Points assigned to indicators were eventually counted and tourist resorts were classified into one of six classes according to the final score, using the following criteria:

- First-level tourist resort ( $\geq 35$ points) - tourist centre (tourist resort with highly developed tourism)

- Second-level tourist resort (30-35 points) - secondary tourist centre (tourist resort with developed tourism)

- Third-level tourist resort (25-30 points) - local tourist centre (tourist resort with medium-developed tourism)

- Fourth-level tourist resort (20-25 points) - developed small tourist resort

- Fifth-level tourist resort (15-20 points) - medium-developed small tourist resort

- Sixth-level tourist resort (<15 points) - under-developed small tourist resort

\footnotetext{
1) Number of inhabitants by 2011 census data (CBS 2013a).

2) Surface area was calculated in GIS using polygon features that comprise the whole administrative area of the settlement (SGA 2013) according to the official Croatian projection co-ordinate system, HTRS 96/TM.

3) The number of classes was determined according to the Sturges rule.
} 


\begin{tabular}{|l|c|c|c|c|c|c|}
\hline \multirow{2}{*}{ Indicator } & \multicolumn{6}{|c|}{ Points } \\
\cline { 2 - 7 } & $\mathbf{1}$ & $\mathbf{2}$ & $\mathbf{3}$ & $\mathbf{4}$ & $\mathbf{5}$ & $\mathbf{6}$ \\
\hline $\begin{array}{l}\text { Number of } \\
\text { tourist beds }\end{array}$ & $<100$ & $100-500$ & $\begin{array}{c}500- \\
1,000\end{array}$ & $\begin{array}{c}1,000- \\
2,000\end{array}$ & $\begin{array}{c}2,000- \\
10,000\end{array}$ & $\geq 10,000$ \\
\hline $\begin{array}{l}\text { Number of } \\
\text { tourist arrivals }\end{array}$ & $<1,000$ & $\begin{array}{c}1,000- \\
5,000\end{array}$ & $\begin{array}{c}5,000- \\
10,000\end{array}$ & $\begin{array}{c}10,000- \\
20,000\end{array}$ & $\begin{array}{c}20,000- \\
100,000\end{array}$ & $\begin{array}{c}\geq \\
100,000\end{array}$ \\
\hline $\begin{array}{l}\text { Number of } \\
\text { overnight stays }\end{array}$ & $<2,000$ & $\begin{array}{c}2,000- \\
10,000\end{array}$ & $\begin{array}{c}10,000- \\
50,000\end{array}$ & $\begin{array}{c}50,000- \\
100,000\end{array}$ & $\begin{array}{c}100,000- \\
500,000\end{array}$ & 500,000 \\
\hline $\begin{array}{l}\text { Beds per 100 } \\
\text { inhabitants }\end{array}$ & $<10$ & $10-50$ & $50-100$ & $100-200$ & $200-500$ & $\geq 500$ \\
\hline $\begin{array}{l}\text { Beds per square } \\
\text { kilometre }\end{array}$ & $<10$ & $10-50$ & $50-100$ & $100-500$ & $\begin{array}{c}500- \\
1,000\end{array}$ & $\geq 1,000$ \\
\hline $\begin{array}{l}\text { Arrivals per } \\
\text { square kilo- } \\
\text { metre }\end{array}$ & $<100$ & $100-500$ & $\begin{array}{c}500- \\
1,000\end{array}$ & $\begin{array}{c}1,000- \\
5,000\end{array}$ & $\begin{array}{c}5,000- \\
10,000\end{array}$ & $\geq 10,000$ \\
\hline \begin{tabular}{l} 
Tourist class \\
\hline
\end{tabular} & - & - & D & C & B & A \\
\hline
\end{tabular}

Tab. 1: Criteria and indicators used in the typology of tourist resorts according to the level of tourism development

\section{Indicators of the intensity of tourism development}

The chapter briefly analyses indicators used to form the typology of tourist resorts in South Dalmatia, according to which the typology of tourist resorts was formed.

\subsection{Number of tourist beds}

In the 2010-2012 period, a total of 66,363 tourist beds were registered in South Dalmatia or $8 \%$ of all registered tourist beds in Croatia (CBS 2011, 2012, 2013b). More than half were registered in Dubrovnik (18,018 beds), the regional tourist centre and leading tourist destination in the research area and the only one with more than 10,000 beds. There are eight more resorts beside Dubrovnik with more than 2,000 registered tourist beds and they make up two thirds of all registered tourist beds in South Dalmatia. These resorts have relatively large populations (in relation to other South Dalmatian settlements), a rather high level of tourism, a higher share of basic accommodation capacities and, besides tourism, other developed economic activities (agriculture, maritime affairs, shipbuilding, industry) or are within the Dubrovnik urban region. Therefore, a certain share of the workforce commutes daily to Dubrovnik to work. 
Class 2,000-10,000 comprises two settlements in the western part of Korčula, in which industry and agriculture prevail in the local economy and tourism is merely a complementary activity. However, the economic crisis and rapid decline in industry forces the local population to re-orient to tourism.

Seven resorts in the class of 1,000-2,000 beds are located in the Dubrovnik Littoral in the wider sense, on Pelješac as well as one in the Lower Neretva Region (Fig. 2).

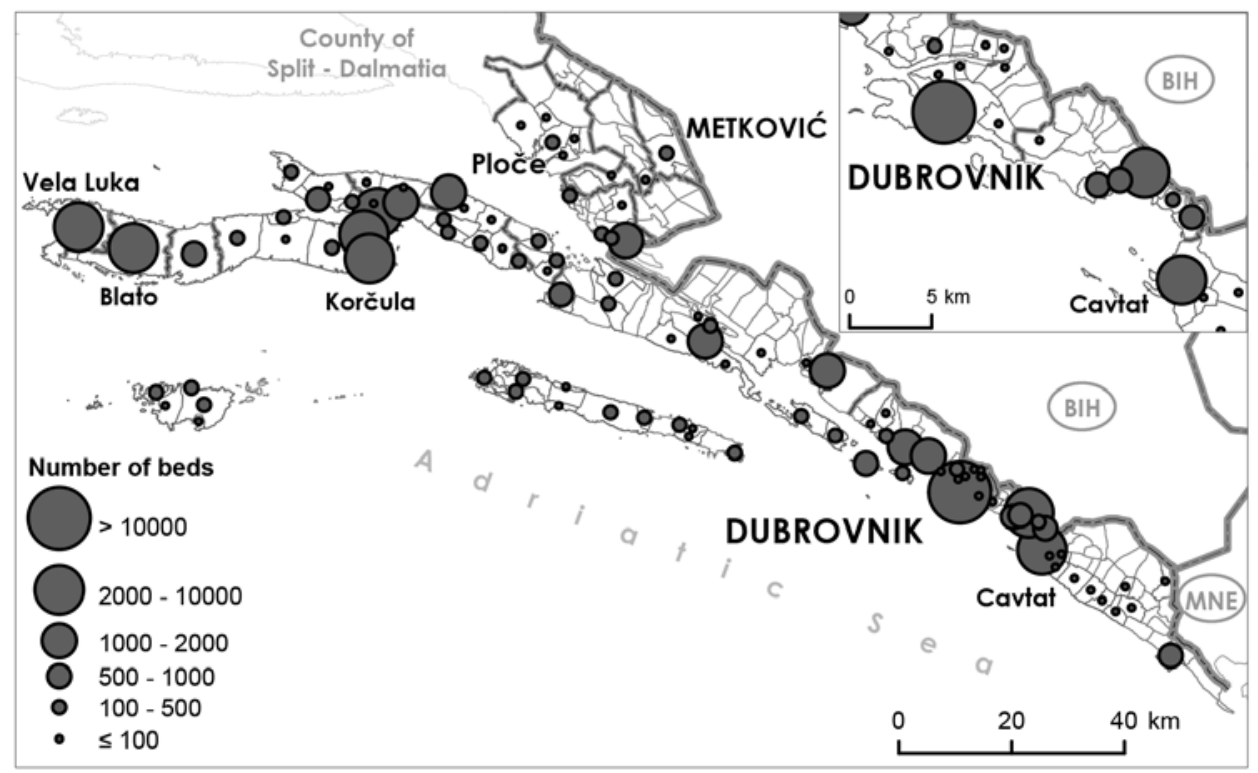

Sources: CBS (2011; 2012; 2013b)

Fig. 2: Number of tourist beds in South Dalmatia (average 2010-2012; by resorts)

Eight resorts that enter the class with 500-1,000 beds can conditionally be divided into two groups: (1) resorts in which tourism is an important economic activity, but is not the only one, and the relatively lower number of tourist beds is related to a lower population number, a higher share of other economic activities in the economic structure and/or developed daily commuting; (2) very small resorts highly oriented to tourism, in which the number of tourist beds largely outweighs the number of inhabitants.

As many as 84 tourist resorts have less than 500 registered beds, among which 49 have less than 100 beds. Generally, these resorts are divided into four groups: (1) very small coastal settlements with a prevalence of private accommodation facilities; located on the islands of Lastovo, Mljet, Koločep and Šipan, on the peninsula of Pelješac and in the Lower Neretva Region; (2) medium and small interior settlements in the Konavle, on Pelješac and on Korčula with developed agriculture and: (2a) developed rural tourism using accommodation facilities within the settlements (in the Konavle and on Pelješac), 
(2b) coastal tourism that takes place in small second-home areas along the coast within the administrative boundaries of interior settlements (on Korčula and Pelješac); (3) coastal settlements with less developed tourism within the Dubrovnik urban region and highly developed daily commuting; and (4) the towns of Ploče and Metković (oriented to agriculture, industry and port functions), in which extensively developed tourism has merely a transit character.

\subsection{Number of tourist arrivals}

The second indicator used in the typology was the number of tourist arrivals that amounted on average to 1,050,619 in South Dalmatia in the 2010-2012 period making up $9.3 \%$ of the total tourist arrivals in Croatia. However, spatial distribution of tourist arrivals indicates major spatial imbalance in tourism turnover (Fig. 3). Dubrovnik, the only tourist destination with more than 100,000 arrivals, recorded $52.3 \%(548,942)$ tourist arrivals, which demonstrates its major role in the tourism of the region.

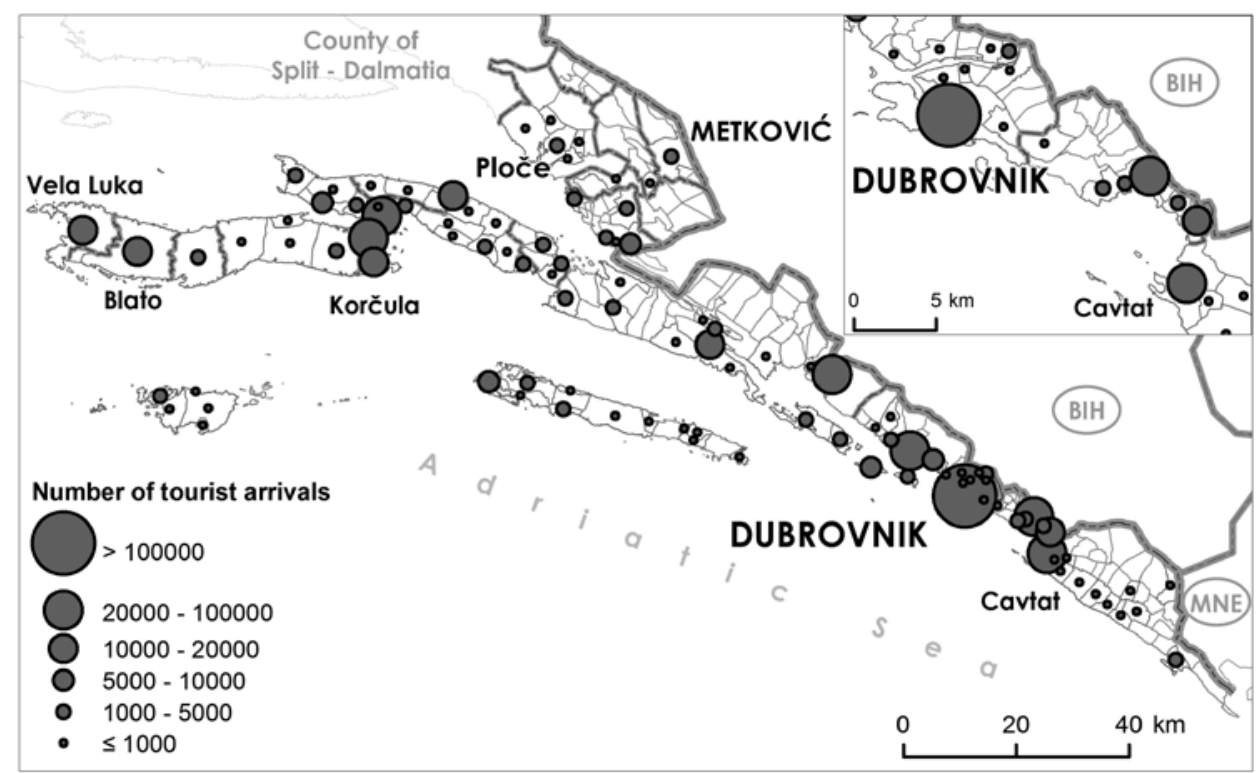

Sources: CBS $(2011 ; 2012 ; 2013 b)$

Fig. 3: Number of tourist arrivals in South Dalmatia (average 2010-2012; by resorts)

The 20,000-100,000 Class comprises tourist resorts with larger populations, a more favourable structure of accommodation capacities with a higher share of hotels, rich attraction basis and complex tourism supply based on coastal tourism, but with other forms of tourism present (nautical, cultural, congress, sports tourism etc.) as well. 
The 10,000-20,000 Class comprises resorts, in which, besides tourism that has an important socio-economic role, other economic activities are developed (e.g., agriculture, mariculture, industry). Therefore, more than 10,000 arrivals are recorded only in the resorts in the Dubrovnik Littoral (in the widest sense), on Pelješac and Korčula, while all the tourist resorts on the islands Lastovo, Mljet and the Elaphites [Elafiti] as well as in the Lower Neretva Region record having less than 10,000 tourist arrivals.

Classes with 1,000-5,000 and 5,000-10,000 arrivals comprise tourist resorts that can be divided into two groups: (1) less-developed tourist resorts in the Dubrovnik Littoral, on Korčula and Pelješac (in which tourism is combined with agriculture and is often related to renting private apartments); (2) leading tourist resorts on the islands (except Korčula), in the Lower Neretva Region and in the Konavle that are more developed in relation to other tourist resorts in those areas. As many as 59 tourist resorts recorded less than 1,000 arrivals.

\subsection{Number of overnight stays}

Spatial distribution of overnight stays has a similar pattern as tourist arrivals, but is influenced by the average length of stay related to the structure of forms of tourism and distance from the mainland. In the 2010-2012 period, an annual average of 4,833,123 was recorded ( $8 \%$ of all recorded overnight stays in Croatia), with almost two fifths in Dubrovnik $(1,862,541)$, the only tourist resort that recorded more than 500,000 overnight stays. The lower share of Dubrovnik in total tourist overnight stays than in tourist arrivals indicates a lower average stay (3.4 days) - that is in concordance with the complex tourism forms developed in Dubrovnik (e.g., cultural and congress tourism) that are characterised by shorter stays.

The 100,000-500,000 Class comprises the resorts with a higher number of tourist arrivals. Those resorts have highly developed tourism (A certain exception is Vela Luka on Korčula, where tourism has not fulfilled its potentials yet.), complex tourism supply and higher population numbers (Fig. 4).

Resorts with 10,000-50,000 overnight stays can be added to the previous group. In these tourist resorts the average stay increases with distance from the mainland and with the level of transport marginality, particularly in the resorts focused only on coastal tourism.

Tourist resorts in the 10,000-50,000 Class comprise the leading resorts on Mljet and Lastovo and in the Lower Neretva Region. In the regions of Korčula, Pelješac, in the Konavle and the Dubrovnik Littoral secondary tourist resorts do enter this class, but they are highly oriented to tourism.

As many as 70 settlements recorded 10,000 or less overnight stays; the majority of small settlements highly dependent upon tourism are on the islands of Mljet, Lastovo and Šipan and seven settlements on Pelješac. The lower number of recorded tourist overnight stays is a consequence of the lower number of tourist beds and arrivals. Tourist resorts in the Dubrovnik Littoral, on Korčula, in the Konavle and the Lower Neretva Region with less than 10,000 tourist overnight stays are heterogeneous in their size and economic structure, but tourism is one of several economic activities in most of them. 


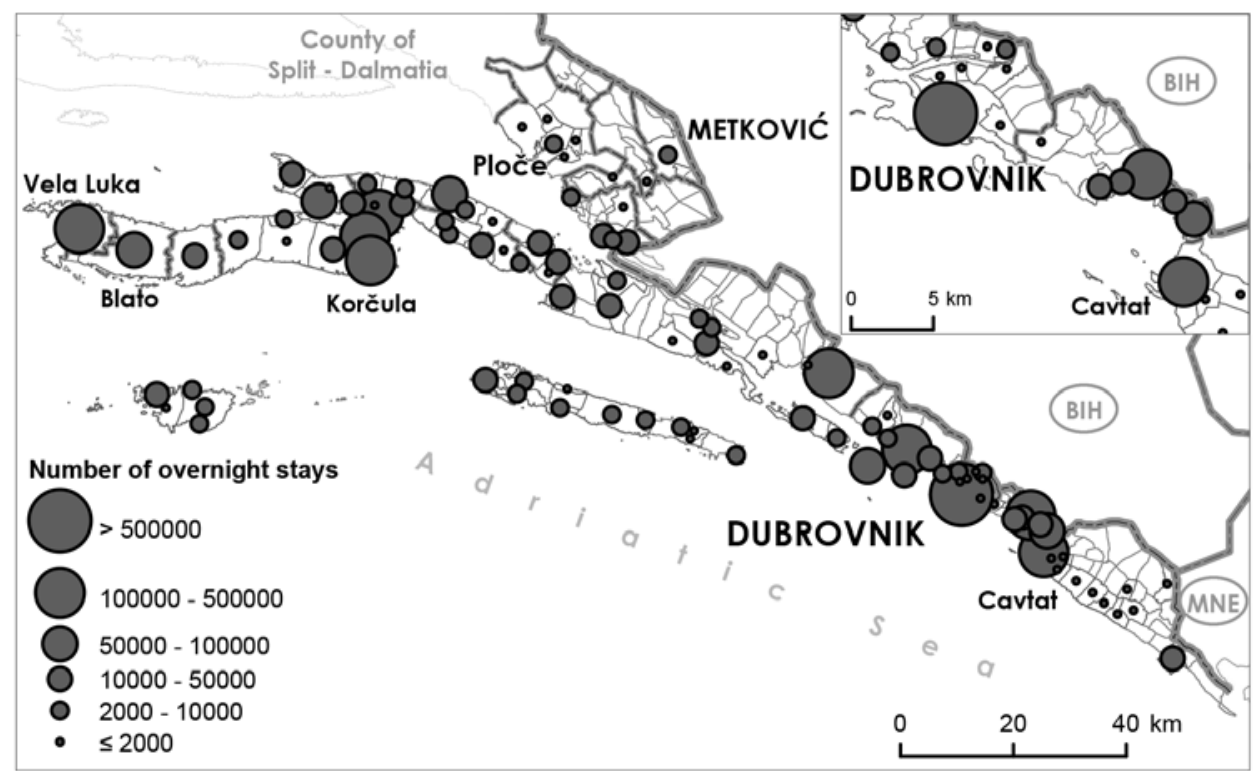

Sources: CBS $(2011 ; 2012 ; 2013 b)$

Fig. 4: Number of overnight stays in South Dalmatia (average 2010-2012; by resorts)

\subsection{Co-efficient of tourist functionality}

The co-efficient of tourist functionality (number of tourist beds per 100 inhabitants) ranks South Dalmatian settlements differently than previous indicators. It represents the social impact of tourism on the local community, i.e., the level of dependency of the local community upon tourism. Therefore, it is expected that the level of tourism functionality is higher in small settlements completely oriented to tourism, while it is lower in larger settlements with complex economic structures.

The average co-efficient in South Dalmatia in the 2010-2012 period was 54.2. Tourist resorts in the 200-500 Class are highly pressured by tourism and are represented predominantly by small settlements (less than 1,000 inhabitants), oriented to tourism and with rather high tourist turnover in relation to their population number. It comprises secondary and lower ranking tourist resorts in the Dubrovnik Littoral and in the Konavle, on Pelješac and the islands of Mljet and Lastovo (Fig. 5).

The intensity of tourism is rather high in tourist resorts with 100-200 tourist beds per 100 inhabitants, which comprise different types of settlements. One group consists of larger settlements with a higher number of tourist beds and overnight stays and complex economic structure, while the other group is represented by small settlements oriented to tourism with a predominance of private accommodation facilities.

The effects of tourism are present in resorts with 5-100 beds per 100 inhabitants, but the population is engaged in other economic activities besides tourism. Due to its complex 
economic and functional structure, Dubrovnik and several larger settlements enter this class.

Tourist resorts with less than 50 beds per 100 inhabitants usually have small populations and tourism is only a complementary activity represented by renting private apartments to tourists.

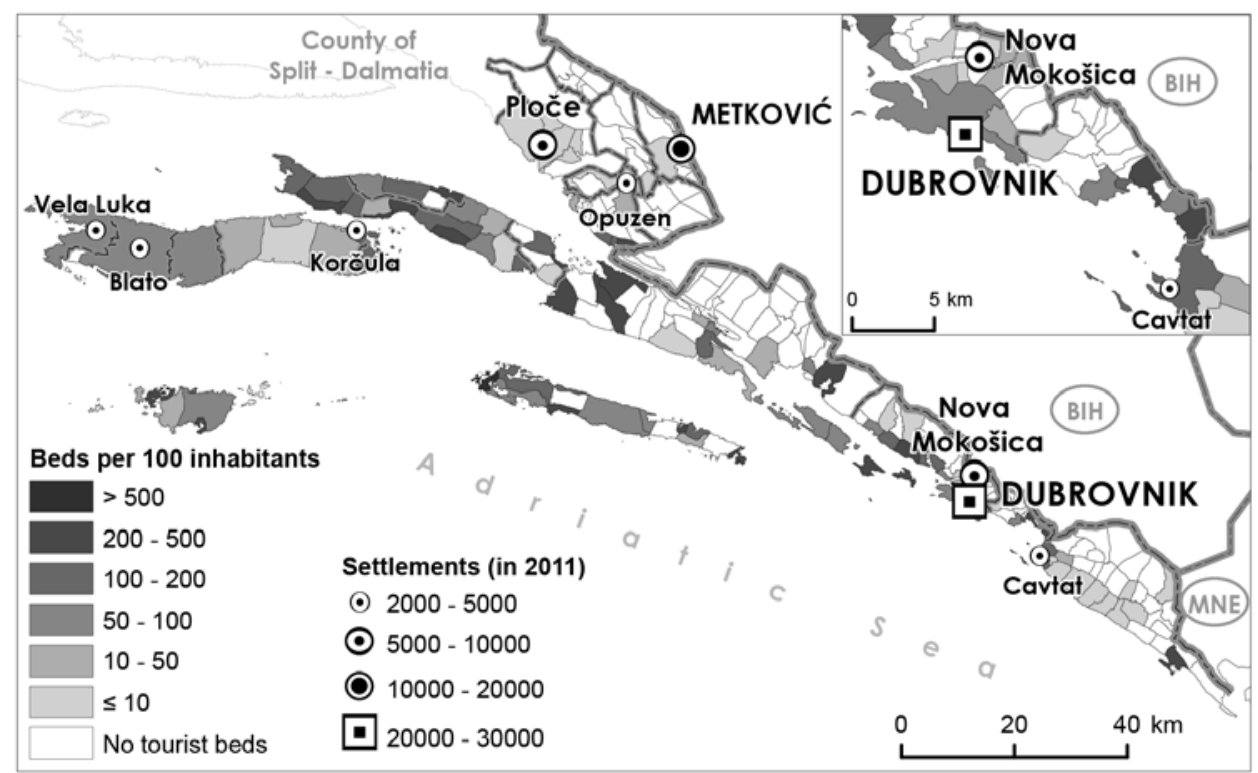

Sources: CBS (2011, 2012, 2013a, 2013b)

Fig. 5: Co-efficient of tourist functionality in South Dalmatia (tourist beds per 100 inhabitants) (average 2010-2012; by resorts)

\subsection{Density of tourist beds}

The density of tourist beds and tourist arrivals are indicators of tourism pressure on settlements. In order to satisfy the condition of including the whole observed area in the study, the densities of tourist beds and arrivals were calculated using the entire administrative area of settlements (built settlements and unbuilt land). Due to significant differences in the surface area of the settlements, tourist resorts largely differ according to density of tourist beds and arrivals. If the administrative area of the settlement is small, tourist resorts often have virtually high intensity of tourism, while rather high intensity of tourism in resorts with small populations can be hidden behind the virtually low density of tourist beds and/or arrivals.

The average density of tourist beds in South Dalmatia in the 2010-2012 period was 37.2 beds per square kilometre, but with major regional differences. A high density of tourist beds $(500-1,000)$ was present in leading tourist resorts, but also in some small resorts with a few tourist beds and a very small administrative area (Fig. 6). 


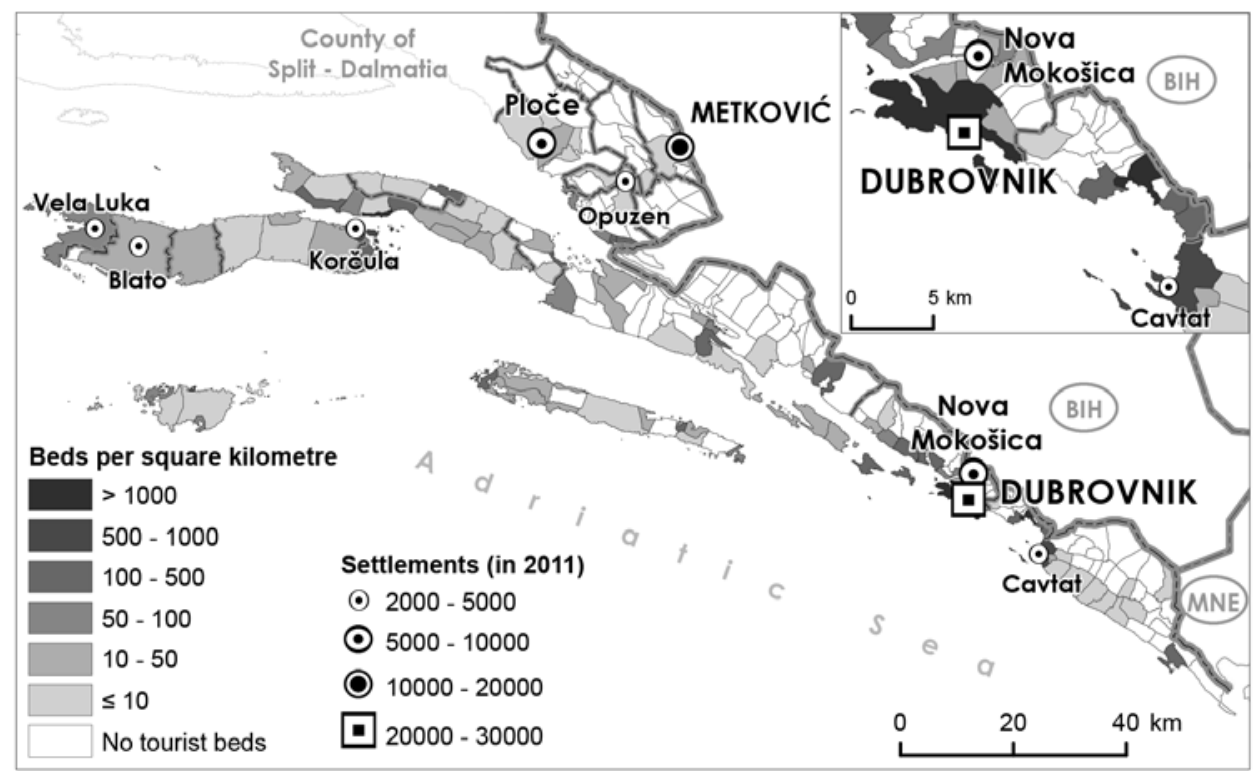

Sources: CBS (2011, 2012, 2013b); SGA (2013)

Fig. 6: Density of tourist beds in South Dalmatia (tourist beds per square kilometre) (average 2010-2012; by resorts)

20 tourist resorts recorded between 100 and 500 beds per square kilometre, predominantly small ones with a very small administrative area and a relatively high number of tourist beds and tourism turnover, which subsequently resulted in a high intensity of tourism in the area. This class comprises settlements in the Dubrovnik Littoral, the Konavle, on the Elaphites, on Korčula and Pelješac, but also in the coastal strip of the Lower Neretva Region and Pomena on Mljet.

The intensity of tourism is lower in resorts with 50-100 beds per square kilometre, characterised by a lower number of tourist beds. As many as 30 tourist resorts have 50100 beds per square kilometre, characterised by fewer tourist beds, less developed tourism and a mild influence of tourism on the area. These resorts are particularly numerous on Mljet, Pelješac and Šipan and include settlements with underdeveloped tourism in the Dubrovnik urban region.

Low density of tourist beds (ten or less beds per square kilometre) was recorded in 38 settlements, predominantly in the rural areas of the Konavle, the Dubrovnik Littoral and Lower Neretva Region and on Pelješac, Mljet and Lastovo.

\subsection{Density of tourist arrivals}

The average number of tourist arrivals per square kilometre of 598.3 in South Dalmatia in the 2010-2012 period indicates a rather high presence of tourism in the area, but with distinct regional differences. 
The highest density of tourist arrivals $(>10,000)$ was registered in distinctively touristified settlements (Fig. 7).

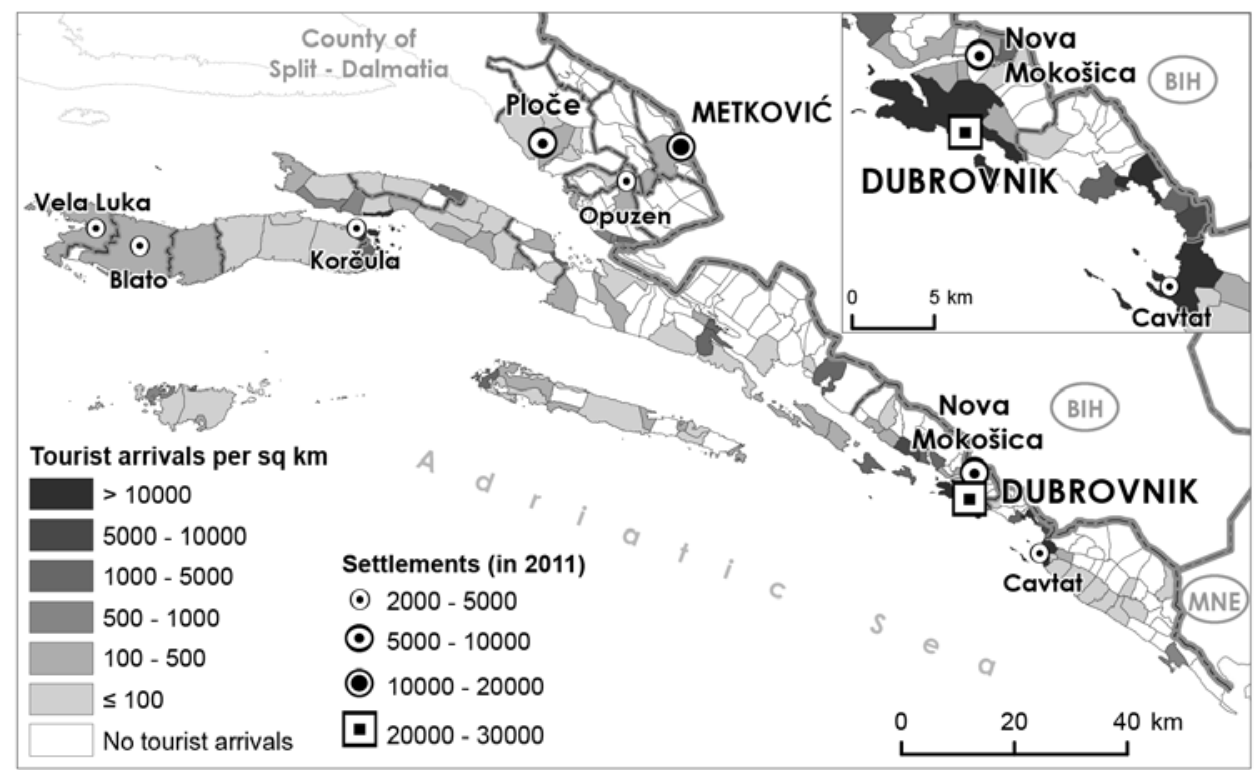

Sources: CBS (2011, 2012, 2013b); SGA (2013)

Fig. 7: Density of tourist arrivals in South Dalmatia (tourist arrivals per square kilometre) (average 2010-2012; by resorts)

A lower but still high concentration of tourists $(1,000-5,000$ arrivals per square kilometre) is recorded in small settlements (by surface area and population) with rather high tourism turnover in the Dubrovnik Littoral in the wider sense, on the Elaphites and on Pelješac and Korčula as well as in leading tourist resorts in the Lower Neretva Region (Klek), on Mljet (Pomena) and on Lastovo. Six resorts with 500-1,000 arrivals per square kilometre have similar features, but with fewer tourist arrivals.

The concentration of tourists is lower in 34 tourist resorts with 100-500 arrivals per square kilometre, but one has to be aware that these resorts are heterogeneous in terms of their surface area, population and tourist arrivals. Nonetheless, they can conditionally be divided into two groups. One group includes settlements with a small administrative area and low tourism turnover, while the other group consists of settlements with a large administrative area and relatively high tourism turnover.

The concentration of tourism is lower in the class with less-developed tourism (100 or less tourist arrivals per square kilometre) that comprises 43 settlements in the Konavle, the Dubrovnik urban region, on Pelješac and Mljet as well as settlements on Korčula with large surface areas. 
The real 'pressure' of tourism in Dubrovnik is much higher than the above-mentioned data show due to the large number of cruise-ship visitors. In 2014, Dubrovnik registered 806,558 cruise-ship visitors from 463 cruise-ships. The most prominent concentration of cruise-ship visitors is from May to October. In the May - October 2014 period, Dubrovnik's Port Authority (2015) registered 384 cruise-ships (82.9\% of all cruise-ships in 2014) and 700,214 cruise-ship visitors (86.8\% of all cruise-ship visitors). It is important to emphasise that the majority of all cruise-ships arrive on Saturday, the day of the weekly shift of tourists in Dubrovnik, which additionally increases the crowds and traffic jams. The highest concentration of cruise-ship visitors is in the Old City, which is visited by more than 10,000 cruise-ship visitors on peak days (ĐUKIć \& JERKOvić 2008). The famous Old City Walls are particularly affected by this phenomenon. Cruising tourism on smaller scale creates environmental and social pressure in the town of Korčula as well.

\subsection{Classes of tourist resorts}

The last indicator included into the typology of tourist resorts in South Dalmatia according to the level of tourism development was the classification of tourist resorts by tourist classes, which included all individually listed settlements in the state regulations.

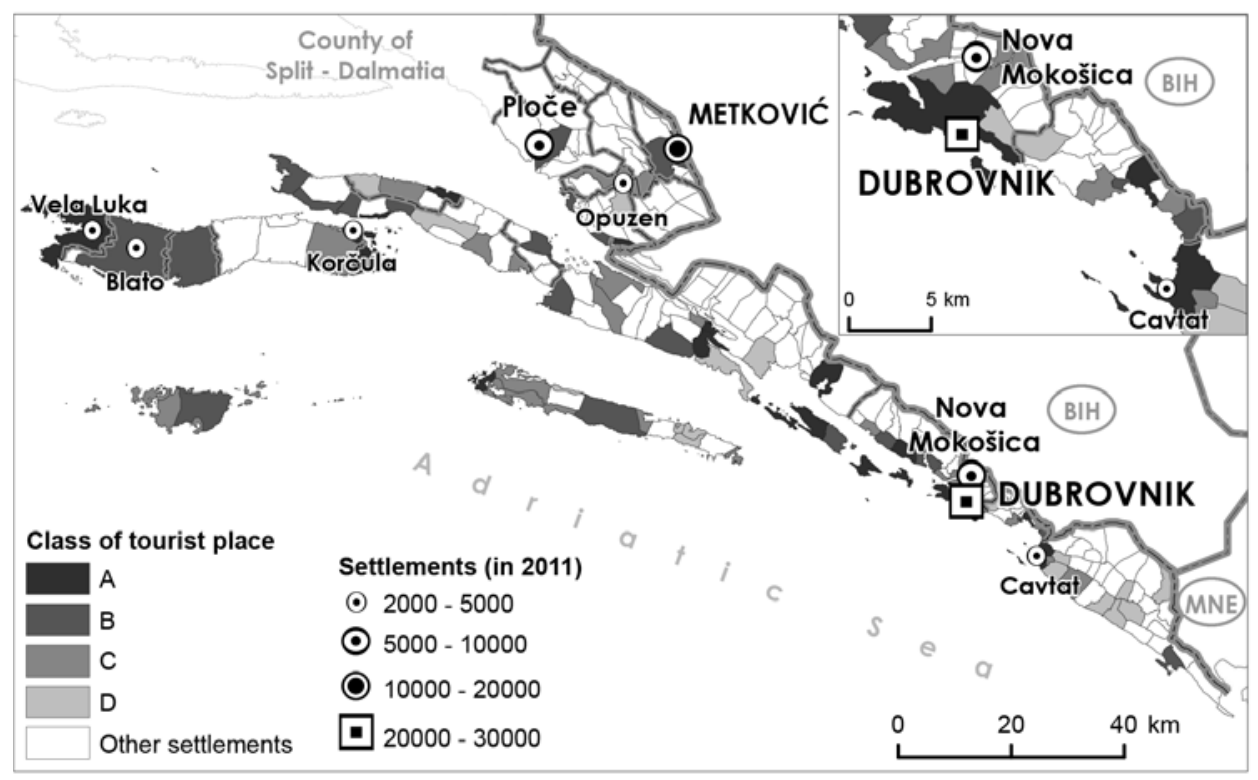

Sources: Regulation on criteria for categorisation of tourist settlements into tourist classes (NN $152 / 08)$

Fig. 8: Classes of tourist resorts in South Dalmatia 
Tourist Class A includes 17 resorts that are attractive to tourists and have all the capacities for tourist visits. Seven settlements in the Dubrovnik Littoral entered this class (including Dubrovnik), i.e., Cavtat in the Konavle, Klek in the Lower Neretva Region, four settlements on Pelješac, three settlements on Korčula and Pomena on Mljet. No tourist resort on Lastovo was listed as Class A.

23 settlements were ranked as Class B, predominantly small attractive tourist resorts, often with underdeveloped tourism infrastructure - in the Dubrovnik Littoral in the wider sense and on Pelješac, four settlements in the Lower Neretva Region, three on Korčula and one in the Konavle, one on Mljet and one on Lastovo.

Class C includes 31 settlements with less-developed tourism infrastructure and tourism generally - three in the Dubrovnik Littoral, three in the Lower Neretva Region, two in the Konavle, six on Pelješac, one on Korčula, four settlements on Lastovo and five small settlements on Mljet.

The largest Class D includes as many as 36 tourist resorts, predominantly small settlements with lower tourism turnover and less equipped for tourists as well as a lower tourist attraction basis. Common features of these settlements are location in the interior, predominantly of rural character, initial phases of tourism development and focus on rural tourism. The other group comprises small coastal settlements with a very simple structure of accommodation facilities (renting private apartments) (Fig. 8).

\section{Typology of tourist resorts in South Dalmatia}

The typology of tourist resorts in South Dalmatia was formed using the previously analysed indicators on the level of tourism development and pressure of tourism on the physical and social environment. The typology included only settlements that had registered accommodation capacities and/or tourism turnover at least in one year in the 2010-2012 period. Each indicator for each tourist resort was assigned from 1 to 6 points, according to the classes defined in the Research Methods chapter. Eventual points assigned to indicators for each settlement were counted, according to which settlements were grouped into six classes (types) according to intentionally determined class boundaries. Although the possible maximum was 42 points, the settlements ranged from 3 to 39 points (Table 2) in reality.

According to this typology, the first-level tourist resorts in South Dalmatia are Dubrovnik (39 points), Orebić (38 points), Mlini (38 points), Cavtat (36 points) and Korčula (36 points). First-level tourist resorts are characterised by highly developed tourism (in terms of accommodation capacities, tourism turnover and structure of the tourist product), and they are centres of tourism regions and represent the carriers of tourism development in South Dalmatia. This type also differs from lower-level resorts by the complexity of tourism supply; e.g., cultural tourism is more present in Dubrovnik and Korčula than in lower-level resorts. Dubrovnik is the leading tourist resort in terms of tourist beds, arrivals and overnight stays, structure of the tourist product and its image on the global tourism market. Hence, the whole tourist region of South Dalmatia can be identified as the Dubrovnik tourism region in its widest sense (Fig. 9). 


\begin{tabular}{|l|l|l|}
\hline Type & Points & Basic features \\
\hline $\begin{array}{l}\text { First-level } \\
\text { tourist resort } \\
\text { (tourist centre) }\end{array}$ & $\geq 35$ & $\begin{array}{l}\text { Highly developed tourist resort. Tourist centre of a wide area. } \\
\text { Rich attraction basis integrated into complex tourism supply. } \\
\text { Highly touristified area. Carrier of tourism development of its } \\
\text { region. }\end{array}$ \\
\hline $\begin{array}{l}\text { Second-level } \\
\text { tourist resort } \\
\text { (secondary } \\
\text { tourist centre) }\end{array}$ & $30-34$ & $\begin{array}{l}\text { Developed tourist resort. Tourist centre in a wider area with less } \\
\text { developed tourism or secondary centre in a developed tourism } \\
\text { area. Rich attraction basis. Coastal tourism is dominant but it } \\
\text { is supplemented by other types of tourism. Carrier of tourism } \\
\text { development of the neighbouring area. }\end{array}$ \\
\hline $\begin{array}{l}\text { Third-level } \\
\text { tourist resort } \\
\text { (local tourist } \\
\text { centre) }\end{array}$ & $25-29$ & $\begin{array}{l}\text { Medium-developed tourist resort highly inclining to tourism. } \\
\text { Coastal tourism is predominant. }\end{array}$ \\
\hline $\begin{array}{l}\text { Fourth-level } \\
\text { tourist resort }\end{array}$ & $20-24$ & $\begin{array}{l}\text { Developed small tourist resort. Settlement with small population } \\
\text { inclined to tourism. Besides in tourism, the local population } \\
\text { works in other economic activities. Predominance of coastal } \\
\text { tourism. }\end{array}$ \\
\hline $\begin{array}{l}\text { Fifth-level } \\
\text { tourist resort }\end{array}$ & $15-19$ & $\begin{array}{l}\text { Medium-developed small tourist resort (in terms of population). } \\
\text { Tourism is one of several economic activities. Simple tourism } \\
\text { supply focuses on coastal tourism and private accommodation. }\end{array}$ \\
\hline $\begin{array}{l}\text { Sixth-level } \\
\text { tourist resort }\end{array}$ & $<15$ & $\begin{array}{l}\text { Underdeveloped small tourist resort. Tourism is a supplement to } \\
\text { other economic activities. }\end{array}$ \\
\hline
\end{tabular}

Tab. 2: Types of tourist resorts in South Dalmatia

Second-level tourist resorts are Slano and Orašac in the Dubrovnik Littoral, Plat in Župa Dubrovačka, Trpanj on Pelješac and Lumbarda on Korčula. These settlements are divided into two groups: (1) highly developed secondary tourist resorts located near first-level tourist resorts (Orašac near Dubrovnik, Plat near Mlini and Lumbarda near Korčula); (2) tourist centres in areas with less-developed tourism (Slano and Trpanj). All second-level tourist resorts are highly oriented to tourism, predominantly coastal tourism, while all other forms of tourism are only a supplement to the basic tourist product. It is important to emphasise that there are no first- or second-level tourist resorts on the islands of Mljet and Lastovo and in the Lower Neretva Region (Fig. 9).

Similarly to second-level tourist resorts, twelve third-level tourist resorts represent local tourist centres in areas with less-developed tourism and resorts with less-developed tourism in highly developed tourism areas. However, they are basically characterised by lower tourism turnover, simpler structure of accommodation capacities and the tourism product. For example, Zaton and Srebreno in the Dubrovnik Littoral in the wider sense are part of the Dubrovnik Riviera and Dubrovnik urban region, while the Sun-\&-Sea-product 


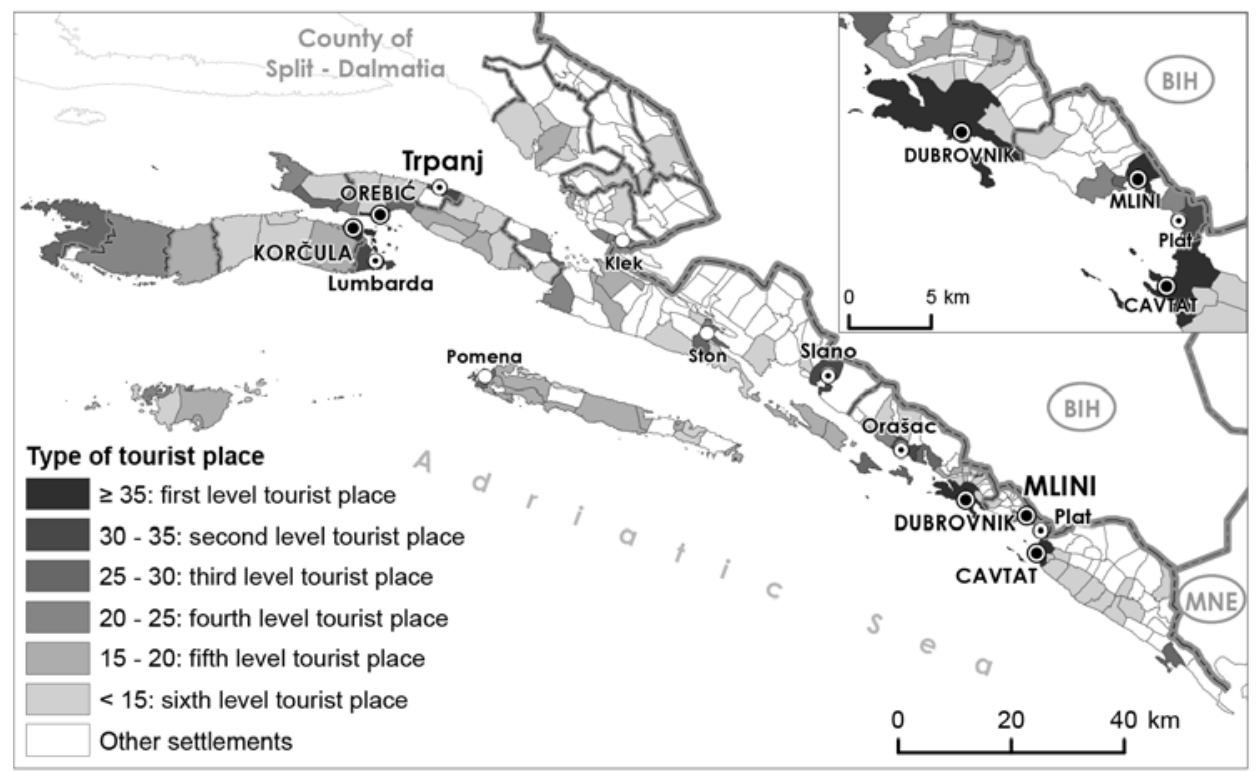

Source: Calculated according to CBS $(2011,2012,2013 a)$; SGA (2013)

Fig. 9: Tourist resorts in South Dalmatia according to type

that has been developed draws on the tourism supply in Dubrovnik. Molunat is a small coastal tourist resort, the only coastal tourist resort in the Konavle besides Cavtat, and is highly oriented to tourism. Klek, a small tourist resort with a tourist village, is a tourist centre of the Lower Neretva Region with less-developed tourism and a number of tourist beds, while the tourism turnover is high in relation to the small population. Despite lower tourism turnover, Ston is the centre of the south-eastern part of Pelješac, based on a specific tourist product and its being a destination for daily excursions. Viganj and Stanković are small tourist resorts within the Orebić Riviera and their tourism product, focused on coastal tourism and drawing on Orebić. Despite an absolutely small number of tourist beds, Pomena in the Mljet National Park [Nacionalni park Mljet], in which the island's only hotel is located, has relatively high tourism turnover and is the tourism centre of the island. Vela Luka in the western part of Korčula recorded a rather high number of tourist beds and tourism turnover, but, due to its orientation to industry and trade, tourism still does not have the social and economic role it could have in respect of its attraction basis and demographic resources.

Fourth-level tourist resorts comprise 13 settlements, mostly small ones (with less than 300 inhabitants), oriented to coastal tourism based on renting private apartments to tourists. Apart from tourism, the local population works in other economic activities (mariculture, agriculture, industry). The exception is the rather large settlement of Blato on Korčula. Although Blato is oriented to agriculture and industry and tourism is limited to areas along the coast with second homes, it records relatively high tourism turnover. 
Another exception is Kupari in the Dubrovnik urban region, in which, despite relatively high tourism turnover, a significant part of the population works in Dubrovnik and is less focused on tourism.

23 fifth-level tourist resorts include small settlements with relatively low tourism turnover recorded predominantly in private accommodation capacities. Besides tourism, the local population is involved in other economic activities, but the level of economic activity is generally low, due largely to the higher share of elderly population.

The group of sixth-level tourist resorts consists of 50 settlements in all regions of South Dalmatia, particularly in the Konavle, the Lower Neretva Region and on Pelješac. Sixth-level tourist resorts in the Dubrovnik Littoral in the widest sense comprise settlements, in which tourism is at its beginnings and is only a complementary activity. In the Konavle, this group comprises small rural settlements in the interior that have been developing rural tourism as a complementary activity to agriculture. Sixth-level tourist resorts on Pelješac are small coastal settlements with simple tourism supply focused on coastal tourism and interior settlements in which rural tourism has been launched. On Mljet and Lastovo, sixth-level resorts are very small settlements, in which the population is involved into other economic activities.

The typology resulted in determining a certain number of first- and second-level tourist resorts, tourist centres that are carriers of tourism development in South Dalmatia and a large number of small settlements with simpler tourism supply, more or less oriented to tourism. It also confirmed the uneven spatial distribution of tourism development in South Dalmatia with the focus on the Dubrovnik urban region and on Korčula as well as the north-western part of Pelješac as secondary tourist areas.

On the other hand, the Konavle (except Cavtat), the north-western Dubrovnik Littoral, south-eastern Pelješac, Mljet and Lastovo and, particularly, the Lower Neretva Region have lower levels of tourism development. The higher level of tourism development is concentrated almost exclusively in coastal tourist resorts, while the interior is characterised by sporadic and low tourism development. (Rural tourism has been moderately developing in the Konavle and in the interior settlements on Pelješac.) However, even in areas with a lower level of tourism, some settlements (particularly small ones) are highly dependent upon tourism and, therefore, are characterised by high pressure of tourism on the physical and social environment. Due to evident pressure of tourism above the carrying capacity limits in some areas in the summer season, tourism planners and local stakeholders are advised to determine the carrying capacity and to establish a more successful tourism management. A possible solution for reducing pressure in the summer season would be diversification of tourism supply, creating new destination products not dependent upon Sun-\&-Sea.

\section{Conclusion}

Typologies of tourist resorts regarding the level of tourism development are often used as a tool for the purposes of spatial planning, in order to determine the poles of tourism de- 
velopment in an area. They ought to be a prerequisite for improving destination plans and improving attractiveness of destination products. The paper identified six types of tourist resorts in South Dalmatia according to the combined set of statistical criteria. Each type has a distinct role in tourism development of the region. The first level of tourist resorts represent highly touristified tourist centres. They carry the development of tourism in their regions. Due to the rich attraction basis integrated into the complex tourism supply, these centres attract tourism demand in their wider regions.

Second-level tourist resorts (secondary tourist resorts) comprise developed tourist resorts (mostly coastal) that have the role of tourist centres in tourism areas with less-developed tourism or have a secondary role in the areas with highly developed tourism. Second-level tourist resorts have their areas of influence, but they are smaller compared to the first-level resorts.

Coastal tourism is predominant in the third-level tourist resorts as well, which incline highly to tourism although tourism is medium-developed.

The last three types of tourist resorts comprise small settlements (small by population) that differ among each other, primarily by the level of tourism development. All of them are characterised by the predominance of accommodation in private households. Fourth-level tourist resorts are characterised by developed tourism, in which one part of the local population is employed in other economic activities. Tourism in the fifth-level resorts is medium-developed and it is only one of the branches of the economy, in which locals are involved. The sixth level of tourist resorts comprises tourist resorts, in which tourism is at the very beginning and only a complementary activity.

The typology of tourist resorts in South Dalmatia based on the criteria analysed proved to be a useful tool for determining the tourism areas' different levels of tourism development as well as the pressure of tourism on the physical and social environment. One has to bear in mind that the criteria used in the typology can be applied to other tourism areas with similar levels of tourism turnover and population, e.g., other seaside regions in Croatia and other Mediterranean countries. However, the criteria would have to be modified in the analysis of regions in the continental part of Croatia or in other countries with a lower level of tourism development, in order avoid a situation, in which almost all settlements would be categorised as lowest-level tourist resorts.

Therefore, the typology of tourist resorts can be treated as a first step needed to conduct functional tourism regionalisation of South Dalmatia in order to form functionally complete tourism units that have high-quality tourism supply and that are capable of successful management of tourism development and tourism impacts, now partly present only in leading tourist resorts. The purpose of more successful and consistent tourism management, for which the typology of tourist resorts and tourism regionalisation are basic pre-conditions, is to stop unplanned, unbalanced and often detrimental development of private accommodation capacities. The aim needs to be the achievement of integral tourism development that includes valorisation of the entire tourism attraction basis, development of a complex tourism product, increase in the quality of accommodation units and improved transport availability. Another important factor is improving the quality of the environment and the well-being of the local population as the basic pillars of sustain- 
able development. Therefore, the authors of this paper suggest the use of this typology in destination planning to evaluate if tourism in an area is developed according to its carrying capacity and sustainable development standards.

\section{References}

Curić Z., GlamuZina N., Opačić V.T. (2012), Suvremeni problemi regionalnog razvoja turizma u Hrvatskoj [Contemporary issues in the regional development of tourism in Croatia]. In: Hrvatski geografski glasnik, 74, 1, pp. 19-40.

DrŽAVNa GEODETSKa UPRAVA (DGU) (ed.) (2013), Središnji registar prostornih jedinica Republike Hrvatske [Central registry of spatial units in the Republic of Croatia]. Zagreb.

DRŽAVNI ZAVOD ZA STATISTIKU (DZS) (ed.) (2011), Turizam u 2010 - interna baza [Tourism in 2010 internal data base], CD-ROM, Zagreb.

DRŽAVNI ZAVOD ZA STATISTIKU (DZS) (ed.) (2012), Turizam u 2011 - interna baza [Tourism in 2011 internal data base], CD-ROM, Zagreb.

DRŽAVNI ZAVOD ZA STATISTIKU (DZS) (ed.) (2013a), Popis stanovništva, kućanstava i stanova 2011.: stanovništvo prema spolu i dobi, po naseljima [Census of population, dwellings and households 2011: Population by age and sex, by settlements]. - http://www.dzs.hr/default_e.htm (Accessed 3 December 2014)

DRŽAVNI ZAVOD ZA STATISTIKU (DZS) (ed.) (2013b), Turizam u 2012 - interna baza [Tourism in 2012 - internal data base], CD-ROM, Zagreb.

Đukić A., Jerković S. (2008), Neki suvremeni sociogeografski procesi u povijesnoj jezgri grada Dubrovnika [Some contemporary socio-geographic processes in the historical Old City of Dubrovnik]. In: Geoadria, 13, 2, pp. 207-225.

ESRI ARCGIS ONLINE: Imagery. - http://www.arcgis.com/home/group.html?q=tags:ArcMap931_ Base \& $t=$ group \&owner $=$ esri $\&$ title $=$ ESRI\%20Maps\%20and\%20Data\&sortField $=$ tit le \&sortOrder=asc\&content $=$ all (Accessed 30 July 2014).

GIS DATA (ed.) (2005), Digitalni atlas Republike Hrvatske [Digital atlas of the Repbulic of Croatia]. Zagreb.

KLARIĆ Z. (1990), Kriteriji za definiranje turističko-geografskih regija (primjer Hrvatske) [Criteria for defining geographic regions related to tourism (the example of Croatia)], Doctoral Dissertation, University of Zagreb.

LOzATO-GiotaRt J.P. (1987), Géographie du tourisme [Geography of tourism]. Paris, Mason.

Lozato-Giotart J.P. (19934), Géographie du tourisme. De l'espace regardé à l'espace consommé [Geography of tourism. From regarded to consumed space]. Paris, A. Colin Publisher.

Lozato-Giotart J.P. (2008), Geografia del turismo [Geography of tourism]. Milano, Hoepli.

LuČKA UPRAVA DUBROVNIK (ed.) (2015), Kružna putovanja i ticanja kružnih putovanja u luci Dubrovnik u 2014 [Cruise and cruise calls in the port of Dubrovnik 2014]. - http://portdubrovnik. hr/statistika/ (Accessed 4 September 2015).

LuKIĆ A. (2012), Mozaik izvan grada - tipologija ruralnih i urbaniziranih naselja u Hrvatskoj [Mosaic outside of the city - typology of rural and urbanized settlements in Croatia]. Samobor, Meridijani.

MedLIK S. (20033), Dictionary of Travel, Tourism \& Hospitality. Oxford, Elsevier.

Pollice F. (2002), Territori del turismo. Una lettura geografica delle politiche del turismo [Territories of tourism. A geographical reader on tourism politics]. Milano, Franco Angeli.

PrideAuX B. (2009), Resort destinations: evolution, management and development. Burlington, Butterworh-Heinemann. 
Pravilnik o kriterijima za razvrstavanje naselja u turističke razrede [Regulation on criteria for categorization of tourist settlements into tourist classes] (2008). In: Narodne novine, 152.

Šulc I. (2014), Turistički razvoj i stagnacija otoka Korčule u modelu razvojnog ciklusa turističkih područja [Tourism development and stagnation on Korčula in the model of the tourism area life cycle]. In: Hrvatski geografski glasnik, 76, 2, pp. 61-84.

VuKonić B., ČAVLEK N. (ed.) (2001), Rječnik turizma [A dictionary of tourism]. Zagreb, Masmedia. Williams S. (20092), Tourism Geography - A New Synthesis. London - New York, Routledge. 